\title{
Arbeidsmarktprognoses Provincie Gelderland
}

Citation for published version (APA):

Peeters, T., \& Cörvers, F. (2018). Arbeidsmarktprognoses Provincie Gelderland. ROA. ROA Fact Sheets No. 010 https://doi.org/10.26481/umarof.2018010

Document status and date:

Published: 01/01/2018

DOI:

10.26481/umarof.2018010

Document Version:

Publisher's PDF, also known as Version of record

\section{Please check the document version of this publication:}

- A submitted manuscript is the version of the article upon submission and before peer-review. There can be important differences between the submitted version and the official published version of record.

People interested in the research are advised to contact the author for the final version of the publication, or visit the DOI to the publisher's website.

- The final author version and the galley proof are versions of the publication after peer review.

- The final published version features the final layout of the paper including the volume, issue and page numbers.

Link to publication

\footnotetext{
General rights rights.

- You may freely distribute the URL identifying the publication in the public portal. please follow below link for the End User Agreement:

www.umlib.nl/taverne-license

Take down policy

If you believe that this document breaches copyright please contact us at:

repository@maastrichtuniversity.nl

providing details and we will investigate your claim.
}

Copyright and moral rights for the publications made accessible in the public portal are retained by the authors and/or other copyright owners and it is a condition of accessing publications that users recognise and abide by the legal requirements associated with these

- Users may download and print one copy of any publication from the public portal for the purpose of private study or research.

- You may not further distribute the material or use it for any profit-making activity or commercial gain

If the publication is distributed under the terms of Article $25 \mathrm{fa}$ of the Dutch Copyright Act, indicated by the "Taverne" license above, 
Maastricht University $\&$ ROA

Arbeidsmarktprognoses Provincie Gelderland 2017-2022

Tim Peeters

Frank Cörvers

\section{ROA Fact Sheet}

ROA-F-2018/10

Researchcentrum voor Onderwijs en Arbeidsmarkt | ROA Research Centre For Education and the Labour Market / ROA 


\section{Arbeidsmarktprognoses Provincie Gelderland 2017-2022}

\author{
Inleiding
}

Als onderdeel van het Project Onderwijs-Arbeidsmarkt (POA) stelt het ROA sinds 2013 tweejaarlijkse regionale arbeidsmarktprognoses op die tegemoet komen aan de toenemende belangstelling voor regionale arbeidsmarktinformatie. Binnen dit kader past ook de voorliggende factsheet met arbeidsmarktprognoses voor de provincie Gelderland. Ook wordt in deze factsheet gerefereerd aan de verwachte arbeidsmarktontwikkelingen in de zes onderliggende arbeidsmarktregio's van Gelderland: Stedendriehoek (ROA-F20I8/IOA), Midden-Gelderland (ROA-F-20I8/IOB), Food Valley (ROA-F-20r8/ıC), Rijk van Nijmegen (ROA-F20I8/IOD), de Achterhoek (ROA-F-20I8/IOE), Rivierenland (ROA-F-20I8/IoF) en Noordwest Veluwe (ROA-F20I8/IOG). ${ }^{\mathrm{D}}$ De arbeidsmarktprognoses in de factsheets bestrijken de periode 2017-2022 en worden weergegeven voor 24 opleidingscategorieën die verdeeld zijn over zes opleidingsniveaus. ${ }^{2}$ Waar mogelijk wordt eveneens een relatie gelegd met zowel de sector- als de opleidingsspecialisatie van de werkgelegenheid in de verschillende regio's. De interpretatie van de prognoses gebeurt steeds vanuit het perspectief van schoolverlaters en werkzoekenden.

Onderstaande kaart geeft weer hoe Gelderland is samengesteld uit de verschillende arbeidsmarktregio's van Nederland.

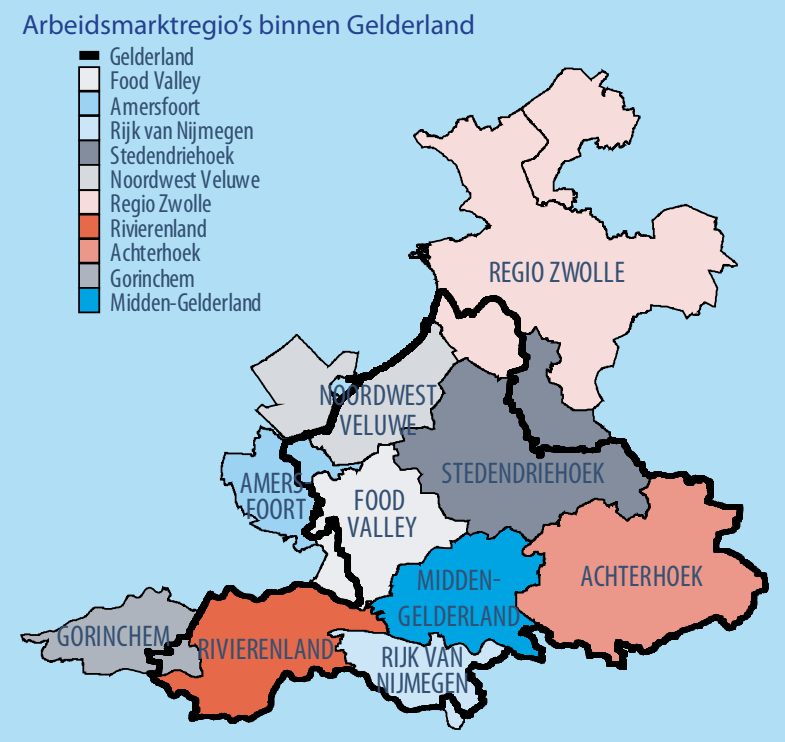

I De regio-indeling is gelijk an die van de UWV-regio's. Voor de UWV-regio Stedendriehoek en Noordwest Veluwe zijn twee afzonderlijke factsheets samengesteld. De arbeidsmarktgegevens zijn echter voor het totaal van beide deelregio's gepresenteerd in de voorliggende en de overige factsheets van Gelderland.

2 Een verdiepende analyse met arbeidsmarktprognoses naar opleidingstype en beroepsgroep kan gevonden worden in factsheet ROA-F-20I8/13.
Drie arbeidsmarktregio's, namelijk Regio Zwolle, Amersfoort en Gorinchem vallen voor een dusdanig klein gedeelte in Gelderland dat ze niet als afzonderlijke arbeidsmarktregio's zullen worden besproken, hoewel hun impact op de Gelderse regio's wel is meegenomen in het model.

\section{Belangrijkste bevindingen}

De belangrijkste bevindingen uit de factsheet kunnen als volgt worden samengevat:

- De verwachte arbeidsmarktperspectieven voor Gelderland als provincie lijken sterk op die van Nederland, maar zijn iets minder gunstig. Als gevolg van een kleinere voorziene uitbreidingsvraag is het totale verwachte arbeidsaanbod in Gelderland nipt groter dan de totale verwachte arbeidsvraag.

- Op geaggregeerd niveau liggen de arbeidsmarktperspectieven in de zeven Gelderse regio's vrij dicht bij elkaar. Het Rijk van Nijmegen heeft de minst gunstige vooruitzichten (licht aanbodoverschot) en Rivierenland de gunstigste (licht vraagoverschot).

- Schoolverlaters die voortijdig uit het basisonderwijs en het vmbo op de arbeidsmarkt instromen kennen relatief goede arbeidsmarktperspectieven als gevolg van een vrij hoge vervangingsvraag op de arbeidsmarkt en een vrij laag arbeidsaanbod. Vaak gaat het echter om kleine banen voor scholieren of om laagbetaalde banen met een zwak loopbaanperspectief.

- Het arbeidsmarktperspectief van hoger opgeleiden is meestal gunstiger dan voor mbo-schoolverlaters. De enige uitzondering hierop is het Rijk van Nijmegen, aangezien in deze arbeidsmarktregio een relatief hoge instroom van hbo en wo-schoolverlaters wordt voorzien, als gevolg van de aanwezigheid van de Radboud Universiteit. In de omliggende regio's zijn er voor hoger opgeleiden beduidend betere baankansen. Dit vereist echter aanpassingen in zoekgedrag en concessies in reistijd of plaats waar men woont. Voor werkgevers in omliggende regio's kan het extra wervingsinspanningen of bemiddelingskosten vereisen.

- Voor mbo-opleidingscategorieën wordt doorgaans een aanbodoverschot verwacht, met uitzondering van mbo 4 techniek.

- Afgezien van mbo $2 / 3$ techniek worden voor technisch geschoolden in alle arbeidsmarktregio's consistent gunstige arbeidsmarktperspectieven verwacht. Dit wordt in de eerste plaats gedreven door een relatief hoge vervangingsvraag. De schaarste aan technisch geschoolden kan een struikelblok vormen voor de invulling van technische vacatures in de bouwnijverheid en in industriesectoren, welke in 
Gelderland proportioneel meer werkenden kennen dan in Nederland.

- De vooruitzichten op een baan in de Gelderse onderwijssector zijn iets minder gunstig dan deze voor Nederland. Dit komt voornamelijk door de lagere uitbreidingsvraag naar schoolverlaters van de opleidingscategorieën hbo- en wo onderwijs dan voor Nederland als geheel.

- De prognoses voor de zorg- en welzijnsgerichte opleidingen liggen overwegend in lijn met deze voor Nederland. Voor zorggerichte mbo-opleidingen wordt een aanbodoverschot verwacht en voor wo medisch een aanbodtekort. Hbo gezondheidszorg kent echter minder gunstige perspectieven dan in Nederland als geheel vanwege een wat kleinere uitbreidings- en vervangingsvraag dan landelijk.

\section{Leeswijzer}

De rapportage voor Gelderland is opgedeeld in acht afzonderlijke factsheets. Naast de voorliggende factsheet met nummer ROA-F-2018/Io die de provincie als geheel bespreekt, zijn er de factsheets die zich specifiek richten op de afzonderlijke Gelderse arbeidsmarktregio's. De structuur van de factsheets is daarbij overal gelijk, behalve dat de factsheet voor Gelderland een aantal extra samenvattende tabellen bevat, alsook een conclusie en verduidelijking bij de interpretatie van de figuren en tabellen.

Elke factsheet begint met een overzicht van de regiospecifieke prognoses en actuele arbeidsmarktcijfers naar opleidingsniveau. Die actuele cijfers omvatten eveneens een overzicht van de sectorspecialisatie van de betreffende regio. $\mathrm{Bij}$ het schatten van de arbeidsmarktprognoses werd rekening gehouden met verhuis- en pendelbewegingen tussen de verschillende arbeidsmarktregio's. De tweede paragraaf vertaalt de geaggregeerde voorspellingen naar opleidingsniveau in prognoses voor 24 opleidingscategorieën, en stelt deze grafisch voor. Daarbij wordt eveneens de relatie getoond tussen de arbeidsmarktperspectieven en het relatieve voorkomen van de opleidingscategorieën in de regio in kwestie. De factsheet voor Gelderland sluit af met een conclusie, en vat daarbij tevens de conclusies van de factsheets van de onderliggende arbeidsmarktregio's samen.

Tekstbox 1 Definities kernbegrippen

\begin{tabular}{|c|c|}
\hline Variabele & Definitie \\
\hline Uitbreidingsvraag & $\begin{array}{l}\text { Vraag naar nieuwe arbeidskrachten die ontstaat door de groei van de werkgelegenheid. Als er sprake is van een werkgelegenheidsdaling, is de uitbreidingsvraag } \\
\text { negatief. }\end{array}$ \\
\hline Vervangingsvraag & $\begin{array}{l}\text { Vervangingsvraag is de vraag naar nieuwe arbeidskrachten die ontstaat door bijvoorbeeld pensionering, (tijdelijke) uittreding vanwege zorgtaken, } \\
\text { arbeidsongeschiktheid, beroepsmobiliteit of doorstroom naar een andere opleiding. }\end{array}$ \\
\hline Arbeidsmarktuitstroom & De som van de vervangingsvraag en de negatieve uitbreidingsvraag. \\
\hline Arbeidsmarktinstroom & $\begin{array}{l}\text { De arbeidsmarktinstroom is het verwachte aanbod van nieuwe arbeidskrachten op de arbeidsmarkt. Deze is gebaseerd op de verwachte uitstroom van } \\
\text { schoolverlaters uit het initiële dag-, deeltijd-, niet-reguliere voltijdonderwijs en de beroepsgerichte volwasseneneducatie. Het weergegeven aanbod in de } \\
\text { figuren } 2 \text { en } 3 \text { is de instroom. Gecorrigeerd voor mobiliteitsstromen tussen arbeidsmarktregio's. }\end{array}$ \\
\hline Baanopeningen & $\begin{array}{l}\text { Baanopeningen zijn de totale vraag naar nieuwkomers op de arbeidsmarkt, zoals deze is bepaald door de werkgelegenheidsgroei (positieve uitbreidingsvraag) } \\
\text { en de vervangingsvraag. In de figuren } 2 \text { en } 3 \text { is dit de vraag naar arbeid. }\end{array}$ \\
\hline ITA & $\begin{array}{l}\text { Indicator Toekomstige Arbeidsmarktperspectief (ITA) van schoolverlaters en werkzoekenden. Deze indicator is gelijk aan een deling van het verwachte aanbod } \\
\text { door de verwachte vraag tot 2022. Naarmate de waarde van de ITA hoger ligt, is er sprake van een slechter arbeidsmarktperspectief. Een waarde tussen 1,01 en } \\
1,05 \text { duidt op een evenwichtssituatie. }\end{array}$ \\
\hline Typering ITA & $\begin{array}{l}\text { Een kwalitatieve beschrijving van de ITA. ITA } \leq 0,85 \text { wordt als "zeer goed" getypeerd, ITA }>0,85 \text { en } \leq 1,00 \text { als "goed", ITA }>1,00 \text { en } \leq 1,05 \text { als "redelijk", ITA }> \\
1,05 \text { en } \leq 1,15 \text { als "matig" en ITA }>1,15 \text { als "slecht". }\end{array}$ \\
\hline Typering loopbaan & $\begin{array}{l}\text { Het bruto uurloon van werkenden in de leeftijdsgroep 40-49 jaar ten opzichte van het bruto uurloon van werkenden in de leeftijdsgroep } 20-29 \text { jaar. Gemiddelde } \\
\text { cijfers voor Nederland in } 2016 \text {. }\end{array}$ \\
\hline Bruto uurloon & $\begin{array}{l}\text { Gemiddeld bruto uurloon van werknemers in euro's. Enquête Beroepsbevolking (EBB) gekoppeld aan het Sociaal Statistisch Bestand (SSB) van het jaar } 2016 . \\
\text { Gemiddelde cijfers voor Nederland in } 2016 .\end{array}$ \\
\hline Werkenden & Minimaal 1 uur werkzaam per week en in de leeftijd 15-74. Cijfers op basis van de Enquête Beroepsbevolking van het CBS. \\
\hline Werkzaamheid & Het percentage werkzaam is de werkzame beroepsbevolking als percentage van de potentiële beroepsbevolking (iedereen ouder dan 15 en jonger dan 75 jaar). \\
\hline Werkloosheid & $\begin{array}{l}\text { Percentage personen die geen betaald werk hebben, wel recent hebben gezocht en daarvoor direct beschikbaar zijn als percentage van de totale } \\
\text { beroepsbevolking (werkzaam en werkloos). }\end{array}$ \\
\hline Vast werk & Personen met een vast dienstverband. Percentage op basis van werknemers in de werkzame beroepsbevolking. \\
\hline Voltijds & Voltijdarbeid betreft personen die minstens 35 uur per week werkzaam zijn. Percentage op basis van de werkzame beroepsbevolking. \\
\hline Leeftijd & Gemiddelde leeftijd. \\
\hline Uren & Gemiddeld aantal uren werk per week. \\
\hline Student/scholier & Percentage van de werkenden met maatschappelijke positie student/scholier. \\
\hline Sectorspecialisatie & $\begin{array}{l}\text { De verhouding tussen het aandeel van het aantal werkenden in een sector in een bepaalde regio ten opzichte van het aandeel van die sector in Nederland. Een } \\
\text { sectorspecialisatiecoëfficiënt groter dan } 1 \text { impliceert dat het aandeel werkenden in de desbetreffende sector in de regio groter is dan in Nederland als geheel. }\end{array}$ \\
\hline Opleidingsspecialisatie & $\begin{array}{l}\text { De ratio van het aandeel personen met een bepaalde opleidingscategorie die wonen in een bepaalde regio ten opzichte van het aandeel van die } \\
\text { opleidingscategorie in het Nederlandse totaal. Indien de specialisatiecoëfficiënt voor een opleidingscategorie groter is dan 1, betekent dit dat de regio in } \\
\text { verhouding tot Nederland een groter aandeel van mensen met deze opleiding kent. }\end{array}$ \\
\hline
\end{tabular}


Teneinde de leesbaarheid van de rapportage te bevorderen, geeft Tekstbox I een overzicht van de definities van de in de factsheets gebruikte variabelen.

\section{Prognoses en actuele arbeidsmarktcijfers naar opleidingsniveau}

Om een eerste globaal beeld te geven van de arbeidsmarktsituatie in Gelderland tijdens de prognoseperiode 2017-2022, toont Tabel I de geaggregeerde arbeidsmarktprognoses voor zowel Nederland als Gelderland en de zeven regio's die (deels) in Gelderland zijn gelegen. De cijfers zijn weergegeven als jaarlijkse percentages van de werkgelegenheid in 20I6. De (niet weergegeven) absolute provinciale aantallen zijn berekend als een gewogen som van de prognoses voor de zeven onderliggende regio's.

De verwachte arbeidsmarktperspectieven voor Gelderland als totaal zijn iets minder goed dan die voor Nederland. Terwijl Nederland jaarlijks naar verwachting gemiddeld 3,7\% per jaar aan baanopeningen zal kennen, is dit slechts $3,4 \%$ voor Gelderland als gevolg van een relatief lage uitbreidingsvraag (o,8\% per jaar). Aangezien de verwachte arbeidsmarktinstroom onderling weinig verschilt, impliceert dit dat de Gelderse arbeidsmarkt wellicht iets minder krap zal zijn dan die van Nederland als geheel.

Er zijn echter belangrijke verschillen tussen de onderliggende arbeidsmarktregio's. Zo zal de werkgelegenheid naar verwachting in de Achterhoek slechts met gemiddeld $0,3 \%$ per jaar toenemen, terwijl dat percentage in Food Valley en het Rijk van Nijmegen I\% bedraagt. In het Rijk van Nijmegen wordt echter wel de kleinste arbeidsmarktuitstroom (gemiddeld 2,5\% per jaar) en de grootste arbeidsmarktinstroom $(3,6 \%)$ voorzien. De meeste baanopeningen worden verwacht in MiddenGelderland en Food Valley (3,6\%), wat niettemin nog steeds minder is dan de raming voor Nederland $(3,7 \%)$. Stedendriehoek en Noordwest Veluwe bevindt zich ten slotte vrij dicht bij de gemiddelde cijfers voor Gelderland als provincie.

Tabel 2 geeft een samenvattend beeld van de arbeidsmarktperspectieven naar opleidingsniveau voor Gelderland, Nederland en de zeven regio's (waarbij Stedendriehoek en Noordwest Veluwe gesplitst zijn in twee deelregio's). Deze arbeidsmarktperspectieven zijn weergegeven door de indicator toekomstig arbeidsmarktperspectief (ITA) en een kwalitatieve typering.

Zoals reeds vermeld in Tekstbox I toont de ITA voor elk opleidingsniveau de verwachte verhouding tussen het totale arbeidsaanbod en de totale arbeidsvraag over de prognoseperiode. Wanneer de ITA tussen I,OI en I,Os ligt, zijn vraag en aanbod min of meer in evenwicht en wordt gesproken van een "redelijk" arbeidsmarktperspectief. Een opleidingsniveau met een ITA groter dan I,O5 krijgt als kwalitatieve typering "matig", en zelfs "slecht" wanneer de waarde groter is dan I,I5. Wanneer het aanbod daarentegen kleiner is dan de vraag en de ITA daardoor kleiner is dan I wordt het arbeidsmarktperspectief als "goed" aangeduid. De typering "zeer goed" geldt bij een ITA kleiner dan of gelijk aan $0,85 .^{3}$

Wat opvalt in de tabel is dat de totale ITA's van de zeven regio's vrij dicht bij elkaar liggen. De minst gunstige vooruitzichten gelden met een ITA van I,04 voor het Rijk van Nijmegen, hoewel dit nog steeds neerkomt op een "redelijk" arbeidsmarktperspectief. De kleinste ITA wordt dan weer verwacht voor Rivierenland $(0,99)$, wat duidt op een licht vraagoverschot. Verder valt op dat voor het mbo in alle arbeidsmarktregio's een aanbodoverschot wordt voorzien, en dat hoger opgeleiden duidelijk zwakkere vooruitzichten kennen in het Rijk van Nijmegen. Vooral voor de groep van hoger opgeleiden loont het zich dus om in de omliggende regio's een baan te zoeken. Zij zullen dan echter concessies moeten doen wat betreft reistijd of woonplaats, en werkgevers zullen hen moeten verleiden om deze stap te zetten.

Tabel 3 splitst de arbeidsmarktprognoses voor de provincie Gelderland verder uit naar opleidingsniveau, en voegt daar actuele cijfers voor een aantal andere arbeidsmarktvariabelen aan toe. Het aantal werkenden in de tabel heeft betrekking op iedereen die minimaal I uur per week werkt en tussen de 15 en 74 jaar oud is. Merk verder op dat verschillen in aantrekkingskracht, inclusief baankansen, tussen arbeidsmarktregio's aanleiding kunnen geven tot pendel- of verhuisbeslissingen van schoolverlaters, als gevolg waarvan deze verschillen kleiner worden. Hiermee is in het prognosemodel rekening gehouden door de arbeidsmarktinstroom per opleidingscategorie in elke arbeidsmarktregio voor dergelijke mobiliteitsbeslissingen te corrigeren.
3 De ITA-typeringen zijn gebaseerd op een statistische analyse van de spreiding van de arbeidsmarktsituatie van de verschillende opleidingstypen. Zie M. Wieling, A. de Grip en E. Willems (I990), Een systematische kwalitatieve typering van arbeidsmarktinformatie, ROA-W-I990/8, Maastricht: ROA. 
Tabel 1

Arbeidsmarktprognoses Gelderland 2017-2022 (gemiddeld percentage per jaar) ${ }^{*}$

\begin{tabular}{|l|l|l|l|l|}
\hline & Werkgelegenheidstoename & Arbeidsmarktuitstroom & Baanopeningen \\
\hline Midden-Gelderland & 0,9 & 2,8 & 3,6 & 2,8 \\
\hline Rijk van Nijmegen & 1,0 & 2,5 & 3,4 & 3,6 \\
\hline Achterhoek & 0,3 & 2,9 & 3,0 & 2,8 \\
\hline Rivierenland & 0,7 & 2,7 & 3,4 & 2,8 \\
\hline Food Valley & 1,0 & 2,8 & 3,6 & 3,3 \\
\hline Stedendriehoek & 0,7 & 2,9 & 3,5 & 2,8 \\
\hline Noordwest Veluwe & 0,7 & 2,7 & 3,3 & 3,0 \\
\hline Gelderland & 0,8 & 2,8 & 3,4 \\
\hline Nederland & 1,0 & 2,8 & 3,7 & 3,0 \\
\hline
\end{tabular}

Gemiddeld jaarlijks percentage van de werkzame beroepsbevolking in 2016

Tabel 2

Arbeidsmarktperspectief (2017-2022) naar regio en opleidingsniveau

\begin{tabular}{|c|c|c|c|c|c|c|c|}
\hline & bo/vmbo & havo/vwo & $\mathrm{mbo} 2 / 3$ & mbo 4 & hbo & wo & totaal \\
\hline \multicolumn{8}{|l|}{ ITA } \\
\hline Gelderland & 0,93 & 1,04 & 1,07 & 1,08 & 1,04 & 0,99 & 1,01 \\
\hline Nederland & 0,90 & 1,03 & 1,05 & 1,04 & 1,01 & 0,98 & 0,99 \\
\hline Stedendriehoek & 0,92 & 0,99 & 1,08 & 1,07 & 1,00 & 0,95 & 1,00 \\
\hline Noordwest Veluwe & 0,92 & 1,03 & 1,14 & 1,11 & 1,03 & 0,81 & 1,01 \\
\hline Midden-Gelderland & 0,93 & 0,99 & 1,02 & 1,07 & 1,03 & 0,95 & 1,00 \\
\hline Food Valley & 0,92 & 1,07 & 1,08 & 1,07 & 1,01 & 0,99 & 1,01 \\
\hline Rijk van Nijmegen & 0,87 & 1,12 & 1,03 & 1,06 & 1,11 & 1,11 & 1,04 \\
\hline De Achterhoek & 0,94 & 1,02 & 1,07 & 1,08 & 1,05 & 0,87 & 1,02 \\
\hline Rivierenland & 0,93 & 0,97 & 1,08 & 1,07 & 0,99 & 0,90 & 0,99 \\
\hline \multicolumn{8}{|l|}{ Typering ITA } \\
\hline Gelderland & goed & redelijk & matig & matig & redelijk & goed & redelijk \\
\hline Nederland & goed & redelijk & redelijk & redelijk & redelijk & goed & goed \\
\hline Stedendriehoek & goed & goed & matig & matig & goed & goed & goed \\
\hline Noordwest Veluwe & goed & redelijk & matig & matig & redelijk & zeer goed & redelijk \\
\hline Midden-Gelderland & goed & goed & redelijk & matig & redelijk & goed & goed \\
\hline Food Valley & goed & matig & matig & matig & redelijk & goed & redelijk \\
\hline Rijk van Nijmegen & goed & matig & redelijk & matig & matig & matig & redelijk \\
\hline De Achterhoek & goed & redelijk & matig & matig & redelijk & goed & redelijk \\
\hline Rivierenland & goed & goed & matig & matig & goed & goed & goed \\
\hline
\end{tabular}


Tabel 3

Arbeidsmarktprognoses (2017-2022) en actuele arbeidsmarktcijfers (2015-2016) Gelderland (GLD) naar opleidingsniveau*

\begin{tabular}{|c|c|c|c|c|c|c|c|}
\hline & bo/vmbo & havo/vwo & mbo $2 / 3$ & mbo 4 & hbo & wo & totaal \\
\hline \multicolumn{8}{|l|}{ Prognoses } \\
\hline Uitbreidingsvraag (\%) & 0,7 & 0,7 & 0,8 & 0,8 & 0,7 & 1,0 & 0,8 \\
\hline Vervangingsvraag (\%) & 3,6 & 1,7 & 2,5 & 2,0 & 2,8 & 3,1 & 2,8 \\
\hline Arbeidsmarktinstroom (\%) & 1,8 & 1,8 & 3,8 & 3,5 & 3,0 & 3,3 & 3,0 \\
\hline ITA (GLD) & 0,93 & 1,04 & 1,07 & 1,08 & 1,04 & 0,99 & 1,01 \\
\hline Typering ITA (GLD) & goed & redelijk & matig & matig & redelijk & goed & redelijk \\
\hline ITA (NL) & 0,90 & 1,03 & 1,05 & 1,04 & 1,01 & 0,98 & 0,99 \\
\hline Typering ITA (NL) & goed & redelijk & redelijk & redelijk & redelijk & goed & goed \\
\hline Typering loopbaan (NL) ${ }^{* * *}$ & slecht & zeer goed & matig & redelijk & redelijk & goed & -- \\
\hline \multicolumn{8}{|l|}{ Actuele indicatoren } \\
\hline Bruto uurloon (NL) ${ }^{* *}$ & 13,7 & 17,3 & 17,7 & 19,2 & 25,1 & 34,7 & - \\
\hline Werkenden $^{* * *}$ & 222.000 & 79.000 & 176.000 & 176.500 & 212.000 & 117.500 & 991.000 \\
\hline Werkzaamheid (\%) & 48 & 61 & 66 & 79 & 76 & 83 & 65 \\
\hline Werkloosheid (\%) & 5 & 5 & 5 & 4 & 3 & 3 & 4 \\
\hline Vast werk (\%) & 68 & 60 & 86 & 86 & 88 & 92 & 81 \\
\hline Voltijds (\%) & 42 & 33 & 53 & 53 & 52 & 60 & 50 \\
\hline Wekelijkse arbeidsduur (uur) & 26,8 & 23,8 & 32,3 & 32,2 & 32,7 & 34,5 & 30,7 \\
\hline Leeftijd werkenden (jaar) & 39,6 & 34,7 & 42,8 & 41,2 & 41,5 & 44,0 & 41,0 \\
\hline Student/scholier (\%) & 23 & 37 & 2 & 4 & 3 & 1 & 10 \\
\hline
\end{tabular}

"Prognoses als gemiddeld jaarlijks percentage van de werkzame beroepsbevolking in 2016; actuele indicatoren als percentage van de werkzame, totale of potentiële beroepsbevolking 2015-2016 (zie Tekstbox 1), tenzij anders aangegeven

** Lonen voor Nederland in 2016

*** Het totaal aantal werkenden voor Gelderland (991.000) wijkt licht af van de optelsom van het aantal werkenden per opleidingsniveau (983.000). Dit komt doordat in het Gelderse totaal ook de werkenden zijn opgenomen waarvan het opleidingsniveau niet is vast te stellen.

Tabel 4

Arbeidsmarktprognoses (2017-2022) en actuele arbeidsmarktcijfers (2015-2016) Nederland naar opleidingsniveau*

\begin{tabular}{|c|c|c|c|c|c|c|c|}
\hline & bo/vmbo & havo/vwo & mbo $2 / 3$ & mbo 4 & hbo & wo & totaal \\
\hline \multicolumn{8}{|l|}{ Prognoses } \\
\hline Uitbreidingsvraag (\%) & 1,0 & 0,9 & 1,0 & 1,1 & 0,9 & 1,1 & 1,0 \\
\hline Vervangingsvraag (\%) & 3,9 & 1,5 & 2,6 & 2,3 & 2,9 & 2,8 & 2,8 \\
\hline Arbeidsmarktinstroom (\%) & 1,9 & 1,7 & 3,9 & 3,5 & 3,5 & 3,3 & 3,0 \\
\hline ITA & 0,90 & 1,03 & 1,05 & 1,04 & 1,01 & 0,98 & 0,99 \\
\hline Typering ITA & goed & redelijk & redelijk & redelijk & redelijk & goed & goed \\
\hline Typering loopbaan & slecht & zeer goed & matig & redelijk & redelijk & goed & -- \\
\hline \multicolumn{8}{|l|}{ Actuele indicatoren } \\
\hline Bruto uurloon & 13,7 & 17,3 & 17,7 & 19,2 & 25,1 & 34,7 & -- \\
\hline Werkenden & 1.768 .500 & 743.500 & 1.426 .000 & 1.343 .500 & 1.835 .500 & 1.140 .500 & 8.348 .500 \\
\hline Werkzaamheid (\%) & 47 & 64 & 66 & 78 & 78 & 85 & 66 \\
\hline Werkloosheid (\%) & 6 & 6 & 5 & 4 & 3 & 3 & 5 \\
\hline Vast werk (\%) & 68 & 60 & 85 & 86 & 88 & 93 & 81 \\
\hline Voltijds (\%) & 42 & 35 & 54 & 52 & 55 & 65 & 51 \\
\hline Wekelijkse arbeidsduur (uur) & 26,7 & 24,8 & 32,5 & 32,3 & 33,0 & 35,3 & 31,1 \\
\hline Leeftijd werkenden (jaar) & 39,4 & 35,1 & 42,9 & 41,2 & 41,4 & 42,4 & 40,8 \\
\hline Student/scholier (\%) & 22 & 36 & 2 & 5 & 4 & 1 & 10 \\
\hline
\end{tabular}

*Prognoses als gemiddeld jaarlijks percentage van de werkzame beroepsbevolking in 2016; actuele indicatoren als percentage van de werkzame, totale of potentiële beroepsbevolking 2015-2016 (zie Tekstbox 1), tenzij anders aangegeven 
De tabel geeft aan dat de verwachte arbeidsmarktperspectieven voor het hoger onderwijs beter zijn dan voor het mbo. Terwijl de perspectieven voor hbo en wo respectievelijk "redelijk" en "goed" zijn, zijn deze voor mbo $2 / 3$ en mbo 4 slechts "matig". Bij mbo 4 is dit voornamelijk het gevolg van een betrekkelijk hoge verwachte instroom $(3,5 \%$ per jaar) in combinatie met een beperkte vervangingsvraag ( $2 \%$ per jaar). De gunstigere perspectieven voor schoolverlaters van hbo en wo worden dan weer sterk gedreven door een relatief hoge vervangingsvraag. Specifiek voor wo draagt ook de hoge uitbreidingsvraag en wat kleinere instroom in verhouding tot hbo-gediplomeerden bij tot het goede arbeidsmarktperspectief. Het feit dat de prognoses (ITA's) voor hbo en wo gemiddeld gunstiger zijn dan voor mbo verhult echter dat dit niet voor alle onderliggende opleidingscategorieën het geval is. Verder stijgt gemiddeld de kans op een vaste en voltijdse betrekking en daalt de kans op werkloosheid naarmate het opleidingsniveau toeneemt. De gemiddelde leeftijd van werkende schoolverlaters uit het basisonderwijs/vmbo of havo/vwo is gevoelig lager dan voor de andere opleidingsniveaus als gevolg van het grote aandeel werkende studenten en scholieren zonder een afgeronde vervolgopleiding.

Opvallend is dat de ITA en dus het toekomstig arbeidsmarktperspectief voor basisonderwijs en vmbo $(0,93)$ gunstiger is dan voor wo $(0,99)$. Dit is een gevolg van de beduidend grotere vervangingsvraag voor werkenden die basisonderwijs of vmbo als opleidingsniveau hebben, alsook van de relatief lage jaarlijkse arbeidsmarktinstroom van schoolverlaters met een dergelijke achtergrond. Deze gunstige perspectieven dienen echter met enige voorzichtigheid geïnterpreteerd te worden. Een aanzienlijk deel van de vraag naar personen met deze opleidingsachtergrond heeft namelijk betrekking op kleine banen. Dit kan afgeleid worden van het relatief lage gemiddeld aantal gewerkte uren per week $(26,8)$ en het hoge aandeel van studenten en scholieren (23\%). Bovendien gaat het vaak om laagbetaalde flexibele banen met weinig doorgroeimogelijkheden. Enerzijds blijkt dit uit het lage bruto uurloon en het percentage dat voltijds en vast in dienst is. Anderzijds komt dit ook tot uiting in het ongunstige loopbaanperspectief. De variabele "typering loopbaan", die per opleidingsniveau kijkt naar de loongroei tussen de leeftijd van 25 en 45 jaar (berekend voor Nederland als geheel), is namelijk het minst gunstig voor laagopgeleiden. ${ }^{4}$

4 De indicator voor loopbaanperspectief wordt berekend aan de hand van het verschil in bruto uurloon van werkenden in de leeftijdsgroep 20-29 jaar en 40-49 jaar. Voor een argumentatie, zie Fouarge, D. Kriechel, B., \& Dohmen, T. (20I4), Occupational sorting of school graduates: The role of economic preferences, Journal of Economic Behavior \& Organization, I06, 335-351.
Om de prognoses en actuele arbeidsmarktcijfers voor Gelderland te vergelijken met deze van Nederland, is eveneens Tabel 4 met de nationale cijfers opgenomen. Wat opvalt, is dat de arbeidsmarktperspectieven (ITA's) van alle opleidingsniveaus op niveau iets gunstiger zijn dan in Gelderland. Meestal is dit het gevolg van een grotere verwachte uitbreidingsvraag, die in Nederland naar verwachting procentueel gezien het grootst zal zijn in de zorg (3,1\% per jaar), de groothandel (I,9\%), de specialistische en zakelijke dienstverlening $(\mathrm{I}, 8 \%)$ en de bouwnijverheid $(\mathrm{I}, 7 \%)$.

Rekening houdend met de verwachte uitbreidingsvraag, vervangingsvraag en arbeidsmarktinstroom, wordt in Nederland de grootste krapte voorzien voor technisch gediplomeerden en, in tegenstelling tot twee jaar geleden, gediplomeerden uit zorg- en welzijnsgerichte opleidingen. Voor technici is dit deels het gevolg van een stijgende vraag naar technisch geschoolden in niet-technische sectoren en beroepen. ${ }^{6}$ De gunstige perspectieven voor opleidingen binnen zorg en welzijn komen deels voort uit de recente beslissing van het huidige kabinet om in de huidige regeerperiode 2,I miljard euro extra te investeren in verpleeghuizen.7 Ook in Gelderland vertaalt zich dit in betere vooruitzichten voor zorg- en welzijnsgerichte opleidingen.

\section{Sectorspecialisatie}

Figuur I geeft voor 2I bedrijfssectoren weer hoe het aandeel van het aantal werkenden ${ }^{8}$ in een sector in Gelderland zich verhoudt tot het aandeel van die sector in Nederland. Dit laat toe om sectoren te identificeren waarin Gelderland gespecialiseerd is. Een sectorspecialisatiecoëfficiënt groter dan I impliceert dat het aandeel werkenden in de desbetreffende sector in Gelderland relatief groter is dan in Nederland als geheel. Voor Gelderland zijn dit voornamelijk de welzijnssector, zorgsector, onderwijssector, de sector landbouw, bosbouw en visserij en de overige industrie. Deze laatste twee sectoren hebben in Gelderland beiden een werkgelegenheidsaandeel dat meer dan $30 \%$ groter is dan het werkgelegenheidsaandeel van Nederland als geheel.

De relatieve focus op landbouw, bosbouw en visserij is echter toe te schrijven aan de sectorcompositie van de

5 Voor meer informatie, zie ROA (2017), De arbeidsmarkt naar opleiding en beroep tot 2022, Maastricht: ROA-R-20I7/IO.

6 Zie hoofdstuk 2 in ROA (2017), Schoolverlaters tussen onderwijs en arbeidsmarkt 20I6, Maastricht, ROA-R-20I7/7.

7 https:/www.nrc.nl/nieuws/20I7/o9/23/geef-2I-miljard-euro-maareens-netjes-uit-13097319-aI574518

8 Gebaseerd op de werkzame beroepsbevolking uit de Enquête Beroepsbevolking (EBB), inclusief zelfstandigen. 
arbeidsmarktregio's Achterhoek en Rivierenland (zie verder), en de specialisatie in de zorgsector wordt dan weer hoofdzakelijk gedreven door het Rijk van Nijmegen. Voorbeelden van sectoren die relatiefondervertegenwoordigd zijn in Gelderland zijn financiële dienstverlening en onroerend goed, energie (met uitzondering van Arnhem) en informatie en communicatie. Deze laatste sector is naar verhouding echter wel sterk aanwezig in het Food Valley.

\section{Arbeidsmarktperspectieven naar opleidingscategorie}

De prognoses naar opleidingsniveau uit de eerste paragraaf kunnen verder uitgesplitst worden naar opleidingscategorie. Dit is weergegeven in Figuur 2, die per opleidingscategorie binnen het lager en middelbaar (beroeps)onderwijs toont hoe de totale arbeidsvraag en het totale arbeidsaanbod zich naar verwachting de komende zes jaar in Gelderland zullen verhouden. Figuur 3 doet hetzelfde voor het hoger onderwijs.

De kleuren bakenen de gebieden af die corresponderen met de vijf eerder besproken ITA-typeringen voor schoolverlaters, gaande van slecht (rood en ITA > I,I5) tot zeer goed (grijs en ITA $\leq 0,85$ ). Deze kunnen geïnterpreteerd worden als een kwalitatieve aanduiding van de verwachte arbeidsmarktperspectieven. Voor de punten op de middelste diagonale lijn zijn verwachte vraag en aanbod aan elkaar gelijk, wat correspondeert met een ITA gelijk aan I. Bijvoorbeeld, voor hbo techniek bedragen het totale aanbod en de totale vraag over zes jaar respectievelijk (afgerond) 22\% en 39\%. Deze waarden impliceren een ITA van 0,89 , zodat hbo techniek zich bevindt in het donkerblauwe gedeelte met het perspectief "goed". 9 Merk op dat deze ITA een gemiddelde betreft van de opleidingscategorie hbo techniek, en dat er variatie kan bestaan in de arbeidsmarktperspectieven van de onderliggende opleidingstypes. ${ }^{\text {I }}$

Wat opvalt, is dat enkel de opleidingscategorie wo techniek zich in het gedeelte bevindt met het perspectief "zeer goed”. Binnen het lager en middelbaar (beroeps)onderwijs hebben afgestudeerden van de meeste opleidingscategorieën redelijke of matige perspectieven. Uitzonderingen hierop zijn basisonderwijs/vmbo en mbo 4 techniek, waarvoor de vooruitzichten voor schoolverlaters goed zijn.

Binnen het hoger onderwijs laten zowel de hbo als wo-opleidingscategorieën een gemengd beeld zien. Slechts twee hbo-opleidingscategorieën hebben een ITA die

9 De berekening van de ITA is niet louter een deling van aanbod en vraag, aangezien teller en noemer nog dienen vermeerderd te worden met Ioo.

Io $\mathrm{Zie}$ de factsheet met nummer ROA-F-20I8/13 voor informatie over de meer specifieke Gelderse prognoses naar opleidingstype en beroepsgroep. kleiner is dan I, namelijk hbo techniek en hbo onderwijs, wat wijst op een goed verwacht arbeidsmarktperspectief voor afgestudeerden van deze richtingen. $\mathrm{Bij}$ de wo-categorieën schommelen de arbeidsmarktperspectieven voor schoolverlaters tussen redelijk en goed. Gemiddeld worden echter voor de meeste hoogopgeleiden betere baankansen verwacht dan voor laag- en middelbaar opgeleiden. Dit is een vaststelling die overigens opgaat voor de meeste arbeidsmarktregio's, doch duidelijk niet voor het Rijk van Nijmegen als gevolg van een relatief grote arbeidsmarktinstroom van hoogopgeleiden door de aanwezigheid van de Radboud Universiteit (zie de betreffende factsheet ROA-F-20I8/IOD). Opleidingscategorieën waarvoor afgestudeerden doorgaans consistent goede of zeer goede arbeidsmarktperspectieven hebben in alle arbeidsmarktregio's, zijn wo techniek en wo medisch.

Ten opzichte van Nederland zijn de vooruitzichten voor deonderwijssector in Gelderland iets minder gunstig. Daarbij zijn de hogere Gelderse ITA's voor hbo- en wo onderwijs voornamelijk het gevolg van een lagere uitbreidingsvraag, welke zelfs licht negatief is voor hbo onderwijs. Aangezien de arbeidsmarktperspectieven voor schoolverlaters en werkzoekenden van hbo- en wo-onderwijs respectievelijk goed en redelijk zijn (bekeken vanuit het standpunt van schoolverlaters en werkzoekenden), kunnen werkgevers van Gelderse onderwijsinstellingen naar verwachting echter wel met enige knelpunten in de personeelsvoorziening te maken krijgen. De zorg- en welzijnscategorieën laten prognoses zien die overwegend in lijn liggen met deze van Nederland, hoewel ze voor de schoolverlaters van hbo gezondheidszorg vanwege een iets kleinere uitbreidings- en vervangingsvraag wat minder gunstig zijn.

Net als bij mbo 4 gelden de gunstigste vooruitzichten binnen hbo en wo voor schoolverlaters van de categorie techniek (goed perspectief), voornamelijk ten gevolge van een relatief hoge vervangingsvraag. Voor schoolverlaters van mbo $2 / 3$ techniek is het arbeidsmarktperspectief daarentegen slechts redelijk. De industriële sectoren, waarvan enkelen relatief sterk vertegenwoordigd zijn in Gelderland (zie Figuur I), kunnen tijdens de prognoseperiode dus te maken krijgen met problemen in de personeelswerving voor technische vacatures op de meeste onderwijsniveaus. 
Figuur 1

Actuele sectorspecialisatie Gelderland ten opzichte van Nederland (2015-2016)

Landbouw, bosbouw en visserij

Voedings- en genotmiddelenindustrie

Chemische industrie

Metaalindustrie

Overige industrie

Energie

Bouwnijverheid

Detailhandel

Groothandel

Vervoer en opslag

Horeca

Informatie en comm unicatie

Financiële dienstverlening en onroerend goed

Specialistische zakelijke dienstverlening

Verhuur en overige zakelijke dienstverlening

Openbaar bestuur en overheidsdiensten Onderwijs Zorg

Welzijn

Cultuur sport en recreatie

Overige dienstverlening, huishoudens

en extraterritoriale organisaties

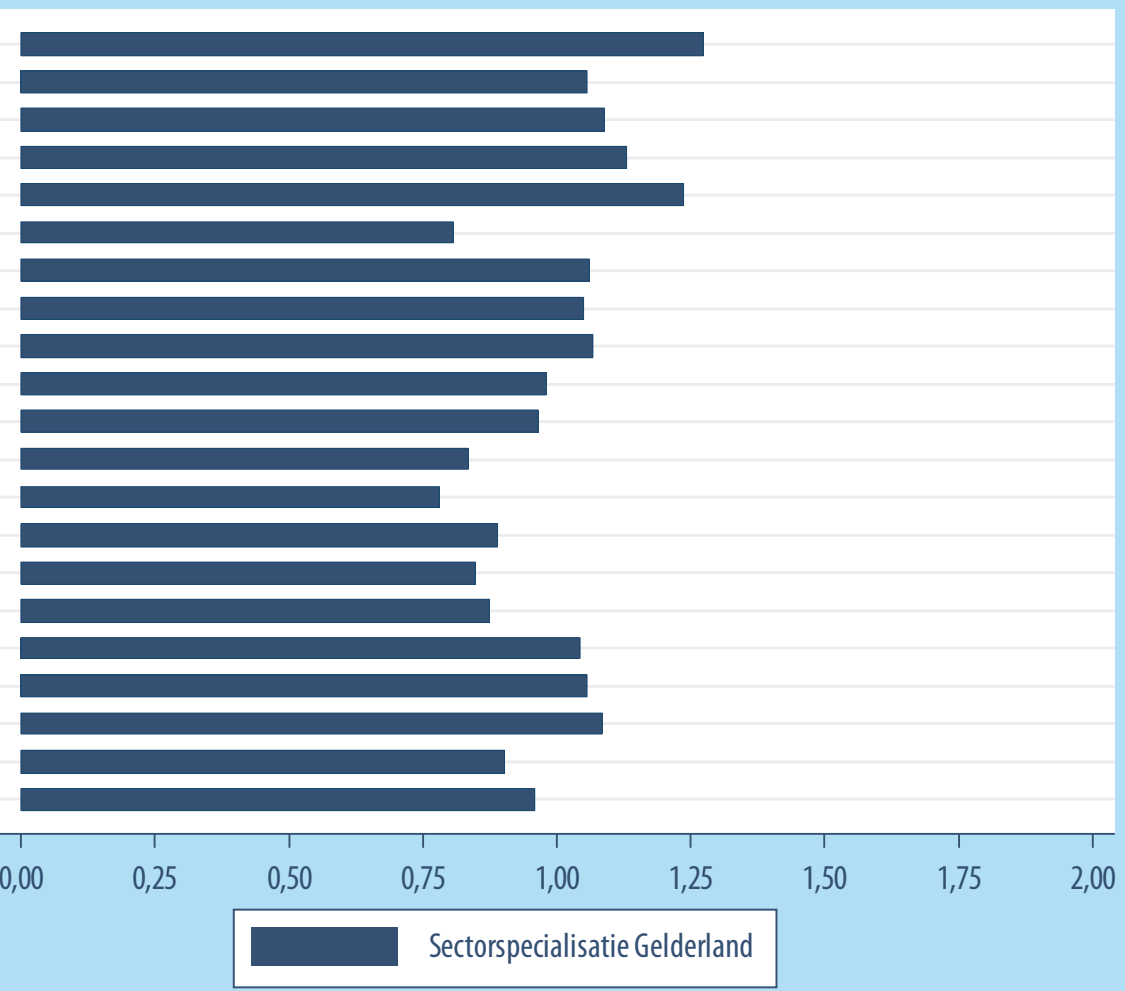

Figuur 2

Vraag en aanbod voor opleidingscategorieën lager/middelbaar (beroeps)onderwijs, Gelderland (beroeps)onderwijs (2017-2022)

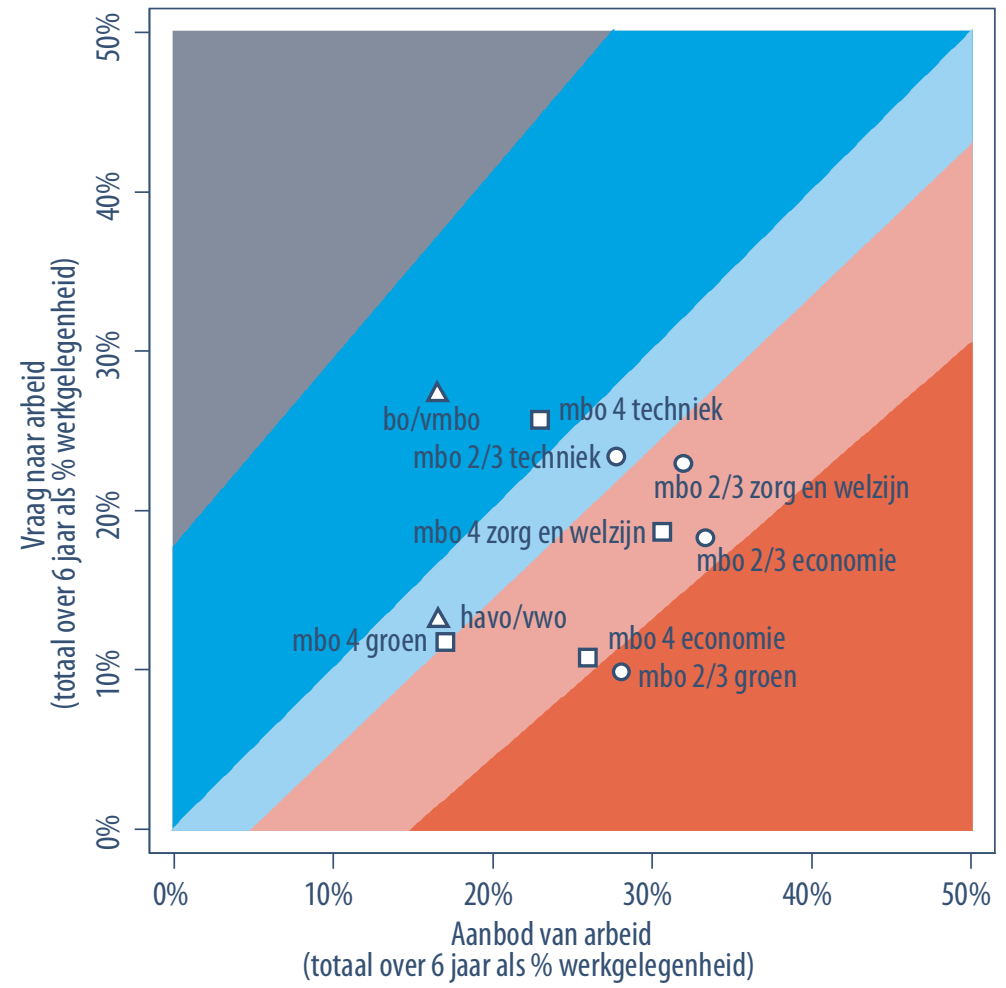

\begin{tabular}{|ll|}
\hline & Perspectief zeer goed \\
& Perspectief goed \\
& Perspectief redelijk \\
& Perspectief matig \\
& Perspectief slecht \\
& bo/vmbo en havo/vwo \\
$\Delta$ & mbo 2/3 \\
$\mathbf{0}$ & mbo 4 \\
\hline
\end{tabular}

(totaal over 6 jaar als \% werkgelegenheid) 


\section{Figuur 3}

Vraag en aanbod voor opleidingscategorieën hoger onderwijs, Gelderland (2017-2022)

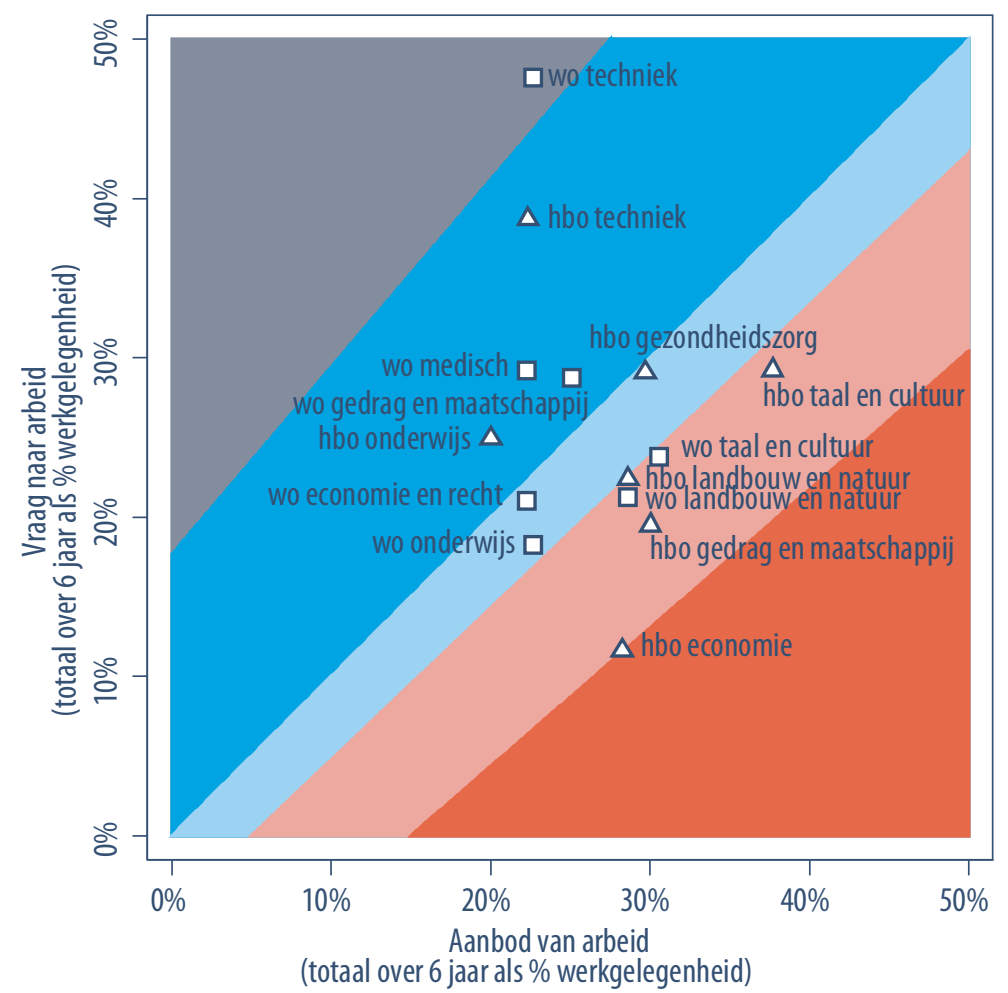

\begin{tabular}{|ll|}
\hline & Perspectief zeer goed \\
& Perspectief goed \\
& Perspectief redelijk \\
& Perspectief matig \\
& Perspectief slecht \\
& hbo \\
$\Delta$ & wo
\end{tabular}

Figuur 4

Arbeidsmarktperspectieven (ITA) versus specialisatie naar opleidingscategorie, Gelderland

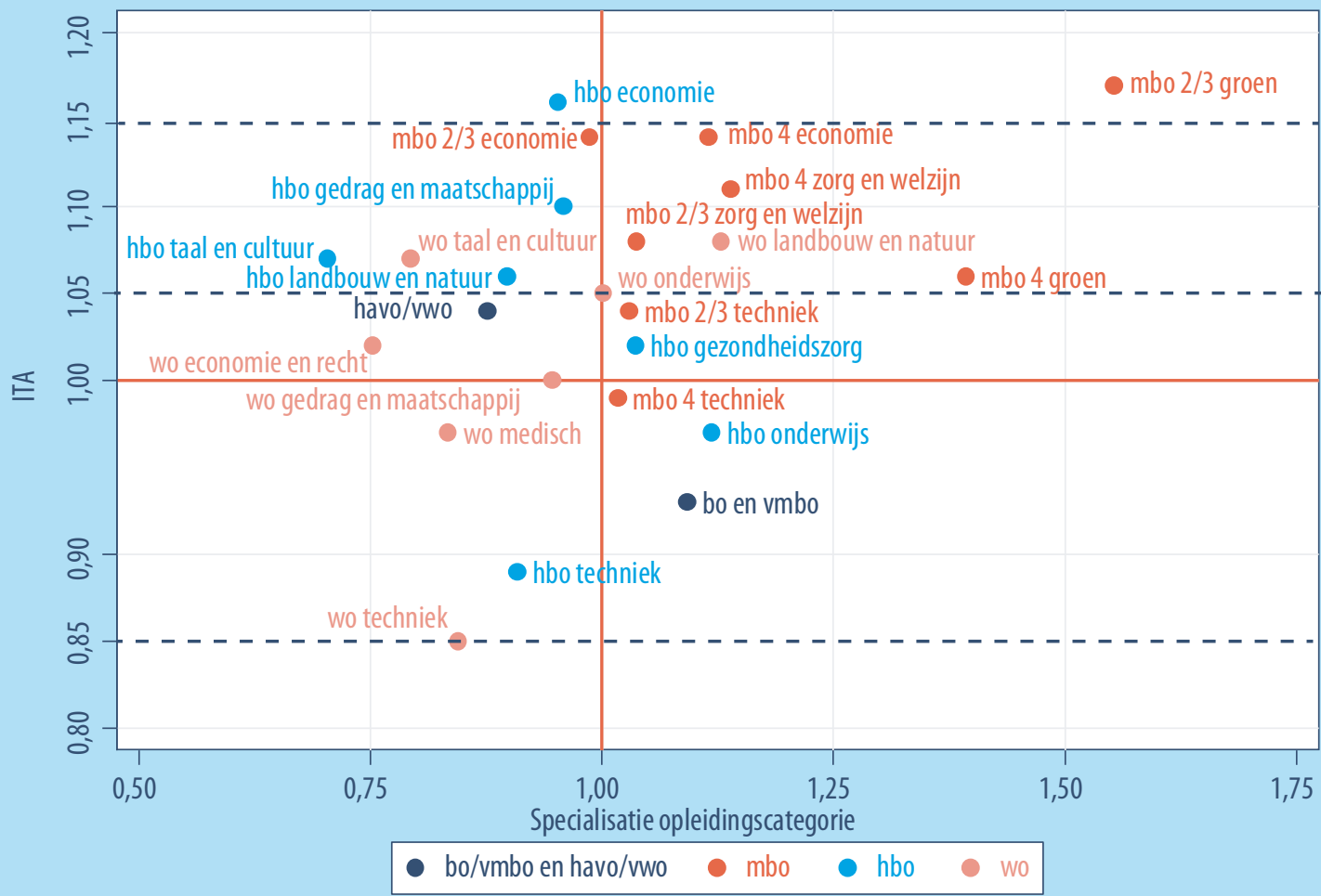


Relatief weinig rekruteringsproblemen voor werkgevers worden daarentegen voorzien voor economische vacatures binnen de detailhandel, groothandel en financiële dienstverlening en onroerend goed, die veel gediplomeerde schoolverlaters uit economische richtingen een baan bieden. Schoolverlaters uit economische richtingen binnen het mbo 2/3, mbo 4 en hbo hebben namelijk wegens een verwacht aanbodoverschot slechts matige arbeidsmarktperspectieven. Hetzelfde aanbodoverschot zal naar verwachting gelden voor afgestudeerden van de opleidingscategorieën mbo $2 / 3$ groen (slecht) en mbo 4 groen (redelijk), die vaak werkzaam zijn in de sector landbouw, bosbouw en visserij en waarin Gelderland een specialisatie in kent.

\section{Relatie arbeidsmarktperspectieven en specialisatie naar opleiding}

Figuur 4 toont de relatie tussen de verwachte arbeidsmarktperspectieven (ITA) voor de verschillende opleidingscategorieën over de periode 2017-2022 en de mate waarin Gelderland in deze opleiding "gespecialiseerd" is. Deze laatste variabele is gelijk aan de ratio van het aandeel werkzame personen met een bepaalde opleidingscategorie die wonen in Gelderland ten opzichte van het aandeel van die opleidingscategorie in het Nederlandse totaal. Indien de specialisatiecoëfficiënt voor een opleidingscategorie groter is dan I, betekent dit dus dat Gelderland in verhouding tot Nederland een groter aandeel van mensen met deze opleiding kent. Bijvoorbeeld, de opleidingsspecialisatiecoëfficiënt van I,55 die hoort bij mbo 2/3 groen impliceert dat het aandeel van deze opleidingscategorie in Gelderland $55 \%$ groter is dan het aandeel van deze opleidingscategorie in Nederland als geheel.

Een eerste vaststelling op basis van de figuur is dat een grotere proportie van een opleidingscategorie in Gelderland ten opzichte van Nederland niet noodzakelijk samengaat met een grotere ITA en dus minder gunstige arbeidsmarktvooruitzichten tot 2022 . Verwachte tekorten komen met andere woorden voor bij opleidingscategorieën die zowel over- als ondervertegenwoordigd zijn. Bijna alle mbo $2 / 3$ - en mbo 4-opleidingscategorieën hebben zowel een ITA als een specialisatiecoëfficiënt die groter is dan I (uitgezonderd mbo $2 / 3$ economie en mbo 4 techniek), met de grootste specialisatie duidelijk voor mbo $2 / 3$ groen.

De opleidingscategorieën op hbo- en wo-niveau tonen een gemengd beeld. Gelderland is het minst gespecialiseerd in de werkgelegenheid van werkenden met een opleidingsachtergrond in hbo taal en cultuur en wo economie en recht, waarvoor tevens de arbeidsmarktperspectieven ongunstig zijn. Hbo onderwijs en wo landbouw en natuur laten de grootste specialisatie binnen het hoger onderwijs zien. Ook het basisonderwijs/vmbo en het havo/vwo geven geen eenduidig beeld. Havo/vwo is in Gelderland licht ondervertegenwoordigd in de werkgelegenheid, wat samengaat met redelijke arbeidsmarktperspectieven (ITA I,O4). Voor basisonderwijs en vmbo geldt dat een oververtegenwoordiging in de werkgelegenheid samengaat met goede arbeidsmarktperspectieven volgens de ITA.

\section{Conclusies $^{11}$}

Als gevolg van een lager dan gemiddelde verwachte uitbreidingsvraag zijn de arbeidsmarktperspectieven voor Gelderland als geheel gemiddeld iets minder gunstig dan voor Nederland. Terwijl voor Nederland namelijk een (beperkt) vraagoverschot wordt voorzien, wordt voor Gelderland een (beperkt) aanbodoverschot verwacht. De beste arbeidsmarktperspectieven gelden voor schoolverlaters van het basisonderwijs/vmbo en het wo, hoewel het loopbaanperspectief op lange termijn voor laagopgeleiden aanzienlijk slechter is en hun gunstige baankansen dikwijls betrekking hebben op kleine en flexibele laagbetaalde banen of op bijbanen voor studenten.

In alle arbeidsmarktregio's zijn de vooruitzichten voor hoger opgeleiden gewoonlijk gunstiger dan voor middelbaar geschoolden. Wel zijn de regio's minder gespecialiseerd in de werkgelegenheid van hoger opgeleiden ten opzichte van Nederland als geheel. Uitzondering hierop vormt het Rijk van Nijmegen, waar een grote voorziene arbeidsmarktinstroom van hoogopgeleiden voor een aanzienlijk overaanbod zorgt dat hun arbeidsmarktperspectieven aantast. Het is belangrijk om afgestudeerden uit deze groep te wijzen op de arbeidskansen in de omliggende regio's van het Rijk van Nijmegen, en om nauw samen te werken met het bedrijfsleven om hun noden af te stemmen op het onderwijslandschap.

Een constante doorheen de prognoses is dat de vooruitzichten voor de meeste technische opleidingen gunstig zijn in alle zeven regio's. Zowel hbo techniek als wo techniek hebben in alle arbeidsmarktregio's goede of zeer goede arbeidsmarktperspectieven, voornamelijk als gevolg van een relatief hoge vervangingsvraag. Daarnaast hebben ook gediplomeerden van mbo 4 techniek in alle arbeidsmarktregio's goede vooruitzichten, behalve in Rivierenland (als gevolg van een vrij grote verwachte instroom). De schaarste aan technisch geschoolden kan een struikelblok vormen voor de invulling van technische vacatures in de bouwnijverheid en in industriesectoren, welke in Gelderland proportioneel meer werkenden kennen dan in Nederland, vooral in de Achterhoek en

II Deze conclusies hebben tevens betrekking op de factsheets voor de onderliggende arbeidsmarktregio's (factsheets IоA, IоB, ІоC, IоD, IoE, IoF). 
delen van Rivierenland en Stedendriehoek en Noordwest Veluwe. Bij het realiseren van de provinciale ambitie uit het beleidskader "Werken aan de economie van de toekomst" om de industriële basis in Gelderland te versterken en de regio de derde industriële provincie van Nederland te maken, dient men derhalve rekening te houden met de verwachte tekorten aan technisch gediplomeerden. ${ }^{\text {I2 }}$

Teneinde tegemoet te komen aan de verwachte tekorten aan technisch personeel en het belang ervan voor de Gelderse sectorstructuur en provinciale toekomstplannen, kan getracht worden om scholieren aan te sporen te kiezen voor technische opleidingen. Tegelijk kan een keuze voor economische of groene mbo-opleidingen ontmoedigd worden om het overaanbod in de meeste van deze richtingen tegen te gaan. Ook kunnen scholieren in mbo 2/3 techniek gestimuleerd worden om door te stromen naar technische opleidingen op een hoger niveau, waarvoor de arbeidsmarktperspectieven significant beter zijn. Oudere werklozen kunnen ten slotte aangezet worden zich om te scholen naar technische beroepen, eventueel door de kosten van volwasseneneducatie voor technische opleidingen te verlagen. Meer algemeen zouden afgestudeerden van mbo-opleidingen met een aanbodoverschot aangespoord kunnen worden zich om te scholen naar mbo-opleidingen waarvoor tekorten verwacht worden.

In lijn met de Nederlandse prognoses zullen de Gelderse zorg- en welzijnssectoren, waarin de provincie een relatief grote werkgelegenheid kent, naar verwachting deels geconfronteerd worden met personeelstekorten. Voor mbo 2/3- en mbo 4 zorg en welzijn worden slechts matige arbeidsmarktvooruitzichten voorzien, zodat rekruteringsmoeilijkheden voor werkgevers hier wellicht weinig zullen voorkomen. De respectievelijk goede en redelijke perspectieven voor wo medisch en hbo gezondheidszorg impliceren daarentegen dat de zorg- en welzijnssectoren voor deze opleidingscategorieën naar verwachting wel wervingsproblemen zullen ondervinden. Voor het Rijk van Nijmegen, dat de grootste specialisatie in de zorgsector kent, wordt echter een aanbodoverschot voorzien van schoolverlaters uit hogere zorgopleidingen, waardoor het van belang is deze groepen te bemiddelen naar vacatures in de andere regio's van Gelderland.
Met betrekking tot de onderwijssector zijn de arbeidsmarktperspectieven voor schoolverlaters en werkzoekenden van hbo onderwijs gunstiger dan voor wo onderwijs. Dit wordt voornamelijk gedreven door een verschillende vervangingsvraag. Een relatief grote vervangingsvraag naar hbo onderwijs zorgt in alle arbeidsmarktregio's behalve Rivierenland voor goede vooruitzichten voor deze opleidingscategorie. De vervangingsvraag naar wo onderwijs is daarentegen aanzienlijk kleiner, zodat de perspectieven voor deze opleidingscategorie gemiddeld slechts redelijk zijn, en in het Rijk van Nijmegen zelfs slecht. In het algemeen geldt echter voor het behoud van hoger opgeleiden in Gelderland dat werkgevers in omliggende regio's van Nijmegen extra wervingsinspanningen voor deze groep moeten leveren.

In de voor Gelderland relatief belangrijke detail- en groothandel worden ten slotte tekorten verwacht voor voortijdig schoolverlaters (basisonderwijs en vmbo), maar niet voor schoolverlaters van mbo 2/3- en mbo 4 economie. Voor deze laatste groepen dreigt daardoor niet per se werkloosheid, maar ook het werken onder het niveau van hun opleiding.
I2 Provincie Gelderland (2016), Beleidskader Economie: Werken aan de economie van de toekomst: Circulair, Innovatief en Internationaal, Arnhem. 


\section{Colofon}

(๑) Researchcentrum voor Onderwijs en Arbeidsmarkt Niets uit deze uitgave mag op enige manier worden verveelvoudigd zonder voorafgaande schriftelijke toestemming van de directeur van het ROA.

\section{Researchcentrum voor Onderwijs en Arbeidsmarkt}

Maastricht University

School of Business and Economics

secretary-roa-sbe@maastrichtuniversity.nl

www.roa.nl

\section{Vormgeving}

ROA secretariaat, Maastricht

juni 2018 